\title{
The Impact of Participative Leadership and Competencies on Performance of Village Fund Management
}

\author{
Anjung Pratama Putri \\ Faculty of Economics and Business \\ Universitas Padjadjaran \\ Winwin Yadiati \\ Faculty of Economics and Business \\ Universitas Padjadjaran
}

\begin{abstract}
The purpose of this study is to examine the effect of participative leadership and competencies on the performance of village fund management. The research subjects in this study are the village head and village apparatus on village governments in the Bandung Regency. The study involves 73 villages selected, adopting a simple random sampling technique. The data was obtained from respondents through a questionnaire instrument. Data were analyzed using descriptive statistical and multiple regression. The result indicates that participative leadership style of the village head and competencies of village apparatus is positively and significantly associated with the performance of village fund management.
\end{abstract}

Keywords: Participative leadership, the Village head, Village apparatus competencies, Village fund management.

\section{Introduction}

The village is the smallest part of the government structure in Indonesia. The village has been given a considerable amount of fund from the central government sourced from the National Indonesian Budget (APBN). The amount of village funds granted in accordance with Law Number 6 of 2014 is 10\%. In addition to village funds received from the central government, the villages also receive Village Fund Allocation (ADD) sourced from the provincial and local government in order to help and support village development. The villages also get funds from the sharing of taxes and levies, provincial financial assistance and original village income (PADes). The village gets a substantial fund and has the authority to manage it. Based on the Minister of Home Affairs Regulation No. 20 of 2018 regarding village financial management, it states that village finance is all village rights and obligations that can be valued in money or everything in the form of money and goods related to the implementation of village rights and obligations.

There are many obstacles and problems experienced in the management ranging from planning to the accountability of village funds. The main problem in village finance is no regulations governing the accounting standards of village governments. Furthermore, regulations governing and fostering village apparatus is regarding village fund accountability not yet established. Village fund planning has also not been carried out based on the mapping of village problems and needs. The implementation of the program development activities has not been fully aligned with the priority scale of the use of village funds. It is because of lack of capacity and personnel in managing village fund. For this reason, villages need to have skilled people to help develop village medium-term development plan (RPJMDes), village work plan (RKPDes) design and cost budget plan (RAB), and village government budget (APBDes).

Problems also occur at the stage of the utilization of village funds, including the existence of misappropriation activities. Those include marking up honorarium, the existence of fictitious projects, reduction in work volume, and unnecessary projects or not according to community needs. With the growing number of new villages, the amount of village budget funds continues to increase each year. In 2019, the total allocation of village funds reached $\mathrm{Rp}$ 
70 trillion. Therefore, the utilization of the village fund must be appropriately managed in order to achieve the goals of the budget itself. Each village is required to use an application called the siskeudes (Village Financial System) that has been provided by the central government in order to facilitate the village in carrying out its activities. The problem that occurs at the regency level is due to the lack of available budget for conducting training or technical guidance for village apparatus at the local government level. Meanwhile, at the village level, the obstacle for the implementation of the siskeudes (Village Financial System) is the lack of village human resources capability in operating computers.

The Corruption Eradication

Commission (KPK) mentioned that problems encountered in relation to managing village funds also occur in terms of managing funds, including the funds which are only managed by the Village Head and stakeholders in the village or only involving the interests of their team without involving the community. The potential problem that will arise from receiving large amounts of the budget is the existence of fraud or corruption at the village government level. Therefore, the transparency of the use of budget and accountability for the Village Government Budget (APBDes) is crucial. The Audit Board of the Republic of Indonesia (BPK) argue that the problems in managing village funds originating from the lack of knowledge of village apparatus in financial governance and reporting.

The local government needs to improve the ability of the apparatus, especially in financial governance and village administration. Furthermore, the leadership factor of the village head is also playing an essential role in managing a village fund. Type of village head who want to participates and receive suggestions and criticisms from subordinates which in turn make the village apparatus motivated to complete the work as much as possible and create an excellent working atmosphere is needed. Furthermore, the village head with a higher level of education and better management experience is required. According to Mujahida (2018), the most critical resources in an organization are human resources or people who give their energy, talent, creativity and effort to the organization. Therefore, in the village administration, the most crucial factor is the village apparatus and the village head.

In addition, Suparman et al. (2014) argue that the factors influencing the success of the implementation process of village fund management are human resource factors. The village head plays a vital role in village fund management because the village head is the holder of the power, which are stipulates the technical implementer of village fund management consisting of the village apparatus. However, in realizing transparency and accountability of village funds utilization is still hampered, due to the low competency of village apparatus ( Satyawati et al., (2017). Therefore, a significant obstacle to proper village fund management lies on the competency of the village apparatus. Besides, the use of village funds is also prone to corruption. Thus, the research problems are formulated as follows: 1) does the participative leadership style of village head affect the performance of village fund management?; 2) does the village apparatus competencies affect the performance of village fund management?

This study was motivated by the fact that there is still a lack of research conducted in Indonesia regarding village fund management. This research contributes in terms of enriching literature in the field of village fund management. The novelty of the study lies in the participative leadership style of the village head which has never been used to test its effect on the performance of village fund management research

\section{Literature Review}

\section{Village Fund Management}

The Minister of Home Affairs Regulation Number 20/2018 explains that the management of village funds is a series of activities that begin with planning, implementation, administration, reporting to the accountability stage carried out in one year from January 1 to December 31 . The village funds management was in the hands of the village head who is assisted by the Village Financial Management Officers (PPKD). According to Regulation of the Minister of Home Affairs Number 20 of 2018 concerning Village Financial Management is carried out in the following stages; 1) planning; 2) implementation, 3) 
administration,

4) reporting and accountability

Planning, according to law number 6/ 2014 regarding village law, it explains that all villages are required to draft development plans, consisting of the village medium-term development plan (RPJM Desa) and village work plan (RKP Desa). The government regulations number 47/2015 states that village medium-term development plan contains the elaboration of the vision and mission of the elected village head and the village development planning policy direction for a period of six years. Meanwhile, according to The minister of home affairs regulation, number 114/2014 states that the village work plan is the elaboration of the village mediumterm development plan covering a one-year period.

Implementation, according to the Indonesia minister of home affairs regulation number 20/2018 explains that the implementation of village finance, there are several general principles that must be followed. All cash income and cash expenditure transactions are carried out through village cash accounts via bank are recorded in the bank book. The apparatus submitting a funding plan to carry out the activity must be accompanied by documents, such as the Budget Plan, Payment Request Letter (SPP), which are first verified by the village secretary and approved by the village head. All village receipts and expenditures must be supported by valid and complete evidence such as invoice, which is first verified by the village treasurer and approved by the village head.

Administration, village finance administration is a recording activity that is specifically carried out by the village treasurer or the head of financial affairs. The village treasurer records the financial transactions that occur. In addition, The government gave a village financial system application called siskeudes which is useful to facilitate the village treasurer in financial management. According to the Indonesia minister of home affairs regulation number 20/2018 concerning village financial management, the administration required is as follows; 1 ) the administration is carried out by the village treasurer; 2) the village treasurer must make recordings of all transactions made in the form of income and expenditure; 3 ) The village treasurer closes the books at the end of each month in an orderly manner; 4) The village treasurer is obliged to account for money through accountability reports.

Reporting, reporting is part of data presentation and information regarding an activity related to the results of work that has been carried out during a specific period as a form of implementation of responsibility for the duties and authorities given (Nurhakim, 2018). Indonesia minister of home affairs regulation number 20/2018 explains that the village head delivers the report to higher rank officers ( Mayor or subdistrict head) periodically. Practically, semesterly report of the realization of the Village Budget (LRA) is submitted by village head to higher rank officers ( Mayor or subdistrict head)

Financial accountability, financial accountability has three main objectives, namely, accountability, managerial, and supervision. The village financial accountability has an accurate and precise focus on reporting time about the use of public funds. The main purpose is to ensure that public funds have been used for objectives that have been established efficiently and effectively (Atmadja, 2018). The accountability report on the realization of the village budget (LRA) is an integral part of the report on the administration of the village. According to the Indonesia minister of home affairs regulation number 20/2018 concerning village financial management, in the accountability of the village government required is as follows:

- The village head submits the village accountability report to higher rank officers ( Mayor or subdistrict head)no later than January. In the village accountability report, the village government budgets (APBDes) shall be attached with format accountability report of village government budgets of the current year, village-owned property report (yearly) and report of central and regional government programs implemented in the village;

- Accountability reports related to the village Government budgets implementation is informed to the public with information media that is easily accessible to the public, such as banners, village website, media bulletin boards, and other media. 


\section{Participative Leadership Style}

A participative leader is a type of leader who involves subordinates in the decision-making process. Aspects of participative leadership style include consultation, joint decision making, power-sharing, decentralization, and democratic management (Yukl, 998). Crimmon (2007) explains that being a participative leader means involving team members in decision making. It happens when creative thinking is needed from team members to solve complex problems or make decisions that will impact other team members. The participatory leadership style emphasizes the high level of support in decision making and policy but with less direction. The style of leader who provides excellent support and direction is slightly referred to as "participative" because the position of control over problem-solving and decision making is held alternately. With the use of this participatory style, leaders and subordinates exchange ideas in problemsolving and decision making.

Participative leadership is related to the use of various decision procedures that allow the influence of others to influence the leaders' decisions. In participative style, leaders and subordinates exchange ideas in problemsolving and decision making. In the context of this research, the village head's leadership should avoid relations with subordinates who only rely on power, and instead need to promote functional cooperation. The village head must also refrain from one-man shows, on the contrary, must emphasize cooperation between colleagues, avoid creating a frightening work atmosphere, and instead need to create conditions that make all subordinates confident.

A research conducted by Satyawati, et al. (2014) and Sunanto, et al. (2016) found that changes in financial performance are influenced by leadership style which means the better leadership style of a leader will be able to influence many people to achieve the expected goals. Also, research conducted by Indah (2019), and Ekaningtyas (2016) revealed that there is a positive relationship between the leadership style of the village head and the accountability of village fund management. A research conducted by Yuliani (2017) and Randhita (2009) shows that the leadership style, which is mostly applied by the urban village head is the participative leadership style and consultative leadership style. So, the extent of participatory leadership style also determines the success of village fund management. Therefore, the hypothesis is proposed as follows:

H1: The adoption of the participative leadership style by village head is positively associated with the performance of village funds management

\section{Competencies}

The competency that must be possessed by a local government is referring to the competency standard set by the National Civil Service Agency (BKN). In the National Civil Service Agency Regulation Number 8/2013 states that technical competence as the ability that every civil servant who covers aspects of knowledge, skills and works attitudes is necessary for carrying out the duties of their position. Thus, the village apparatus need to have professional knowledge, skills and work attitude to perform their works or duties.

A proper village funds management must have a competent village apparatus. It can be achieved through education and training. In line with the stewardship theory, officials who serve as public servants have an obligation to conduct their activities with the accountability principle. Therefore, the decision making in the use of village funds will produce the best decisions to provide the best service in accordance with rules and regulations. Research conduct by Mada, et al. (2017), Rosyidi (2018), Agung (2018), Irma (2015), Makalalag (2017) and Fajri (2015) revealed that there has a positive relationship between the competence of village apparatus and the accountability of village fund management. It indicates that the higher the competency of village apparatus, the higher the accountability of village fund management will be. Therefore, the hypothesis is proposed as follows:

$\mathrm{H} 2$ : The village apparatus competencies is positively associated with the performance of village funds management

\section{Research Method}

This study used a descriptive method with a quantitative approach. The population of this 
study was all village in Bandung Regency. The sampling technique used in this study is simple random sampling. The total sample involved in this study is 73 village in Bandung Regency. Respondents surveyed from each village are as many as three individuals, who are one village head and two village apparatus (especially those who serve as treasurer or head of financial affairs and head of planning affairs). The total respondents obtained is as many as 219 individuals.
Sources of data in this study were; 1) Respondents from the village government, namely village head and village apparatus using a questionnaire and 2) Village data obtained from the Bandung Regency government office such as documents about funds received by the village and previous studies related to village fund management. Classic assumption test and multiple regression analysis were conducted in this study. Variable measurement presented in table 1:

Table 1. Variable Measurement

\begin{tabular}{|c|c|c|c|c|}
\hline Variable & Dimension & $\begin{array}{c}\text { Measurement } \\
\text { Scale }\end{array}$ & Item & Source \\
\hline $\begin{array}{c}\text { The Participative } \\
\text { Leadership Style of } \\
\text { Village Head }\end{array}$ & $\begin{array}{ll}\text { - } & \text { Consultation } \\
\text { - } & \text { Joint Decision Making } \\
\text { - } & \text { Sharing Power } \\
\text { - } & \text { Decentralization and } \\
& \text { Democratic Management }\end{array}$ & Interval and Likert & 11 & Yukl (1998:102) \\
\hline $\begin{array}{l}\text { Village Apparatus } \\
\text { Competencies }\end{array}$ & $\begin{array}{ll}\text { - } & \text { Skills } \\
\text { - } & \text { Knowledge } \\
\text { - } & \text { Work Attitudes }\end{array}$ & Interval and Likert & 9 & $\begin{array}{c}\text { The National Civil Service } \\
\text { Agency Regulation } \\
\text { Number } 8 \text { of } 2013\end{array}$ \\
\hline $\begin{array}{l}\text { Village Fund } \\
\text { Management }\end{array}$ & $\begin{array}{l}\text { - } \text { Transparent } \\
\text { - Accountable } \\
\text { - Participative } \\
\text { - Orderly and Budget } \\
\text { Discipline }\end{array}$ & Interval and Likert & 10 & $\begin{array}{l}\text { The Minister of Home } \\
\text { Affairs Regulation Number } \\
20 \text { of } 2018\end{array}$ \\
\hline
\end{tabular}

\section{Results and Discussion}

\section{Descriptive Analysis}

Questionnaires were distributed directly to respondents, namely village head and village

Table 2. Respondents Demographics apparatus in 73 villages in Bandung Regency. A total of 219 questionnaires were completed and fulfilled the requirements. Detailed information on respondents are presented in Table 2 below:

\begin{tabular}{|c|c|c|}
\hline Demographics & Total & Percentage \% \\
\hline \multicolumn{3}{|l|}{ Gender } \\
\hline Male & 172 & $78,54 \%$ \\
\hline Female & 47 & $21,46 \%$ \\
\hline \multicolumn{3}{|l|}{ Level of Study } \\
\hline High School & 172 & $78,54 \%$ \\
\hline Associate Degree & 4 & $1,83 \%$ \\
\hline Bachelor & 39 & $17,80 \%$ \\
\hline Master & 4 & $1,83 \%$ \\
\hline \multicolumn{3}{|l|}{ Position } \\
\hline Village Head & 73 & $33,33 \%$ \\
\hline Head of Financial Affairs & 69 & $31,51 \%$ \\
\hline Head of Planning & 30 & $13,70 \%$ \\
\hline Village Treasurer & 28 & $12,79 \%$ \\
\hline Head of General Affairs & 9 & $4,11 \%$ \\
\hline Finance Staff & 5 & $2,28 \%$ \\
\hline Village Secretary & 3 & $1,36 \%$ \\
\hline Head of Program and Reporting Affairs & 1 & $0,46 \%$ \\
\hline Head of Service Section & 1 & $0,46 \%$ \\
\hline
\end{tabular}


In order to provide an overview of each variable, the results of respondents' responses are distributed based on scores and average scores on each dimension of the variable. The result is presented in Table 3 .

Table 3. Assessment Results

\begin{tabular}{|c|c|c|c|c|c|c|c|c|c|c|}
\hline \multirow{2}{*}{$\begin{array}{c}\text { Total } \\
\text { Questions }\end{array}$} & \multirow{2}{*}{ Dimention } & \multicolumn{6}{|c|}{ Distribution of Respondents Responses } & \multirow{2}{*}{$\begin{array}{l}\text { Total } \\
\text { Score }\end{array}$} & \multirow{2}{*}{$\begin{array}{l}\text { Percentage } \\
\text { Score }\end{array}$} & \multirow{2}{*}{$\begin{array}{l}\text { Average } \\
\text { Score }\end{array}$} \\
\hline & & 5 & 4 & 3 & 2 & 1 & Total & & & \\
\hline 3 & Consultation & 189 & 151 & 91 & 7 & 0 & 438 & 1836 & $83.8 \%$ & 4.19 \\
\hline 3 & Decision Making & 163 & 162 & 110 & 3 & 0 & 438 & 1799 & $82.1 \%$ & 4.11 \\
\hline 2 & Sharing Power & 98 & 108 & 83 & 3 & 0 & 292 & 1177 & $80.6 \%$ & 4.03 \\
\hline 3 & $\begin{array}{c}\text { Decentralization and } \\
\text { Democratic Management }\end{array}$ & 185 & 178 & 72 & 3 & 0 & 438 & 1859 & $84.9 \%$ & 4.24 \\
\hline \multicolumn{7}{|c|}{ The Participative Leadership Style of Village Head Variable Score } & 1606 & 6671 & $83.1 \%$ & 4.15 \\
\hline $2 \mid$ & \begin{tabular}{|c|} 
Skills \\
\end{tabular} & 120 & 93 & 74 & 3 & 2 & 292 & 1202 & $82,3 \%$ & 4,12 \\
\hline 4 & Knowledge & 259 & 213 & 108 & 3 & 1 & 584 & 2478 & $84,9 \%$ & 4,24 \\
\hline 3 & Attitude & 187 & 165 & 81 & 5 & 0 & 438 & 1848 & $84,4 \%$ & 4,22 \\
\hline \multicolumn{7}{|c|}{ Village Apparatus Competencies Variable Score } & 1314 & 5528 & $84,1 \%$ & 4,21 \\
\hline 3 & Transparent & 224 & 262 & 158 & 13 & 0 & 657 & 2668 & $81.2 \%$ & 4.06 \\
\hline 4 & Accountable & 351 & 344 & 149 & 29 & 3 & 876 & 3639 & $83.1 \%$ & 4.15 \\
\hline 2 & Participative & 196 & 168 & 72 & 2 & 0 & 438 & 1872 & $85.5 \%$ & 4.27 \\
\hline 1 & Orderly And Budget Discipline & 103 & 93 & 22 & 1 & 0 & 219 & 955 & $87.2 \%$ & 4.36 \\
\hline \multicolumn{7}{|c|}{ Village Fund Management Variable Score } & 2190 & 9134 & $83.4 \%$ & 4.17 \\
\hline
\end{tabular}

Based on the assessment result for each variable in Table 3, it indicates that the participative leadership style of the village head and village fund management were obtained at $83.1 \%$ and $83,4 \%$ of the ideal score. It means they are falling in the "good" categories. Meanwhile, the village apparatus competencies were obtained at $84,1 \%$ of the ideal score, which means it is falling in the "very good" categories.

\section{Multiple Linear Regression Analyses}

Multiple linear regression analyses were performed to predict the relationship between independent variables and dependent variables. The dependent variables in this study are village fund management and independent variables in this study is the participative leadership style of the village head and village apparatus competencies. The results of multiple regression are presented in Table 4.

Table 4. Multiple Linear Regression Results

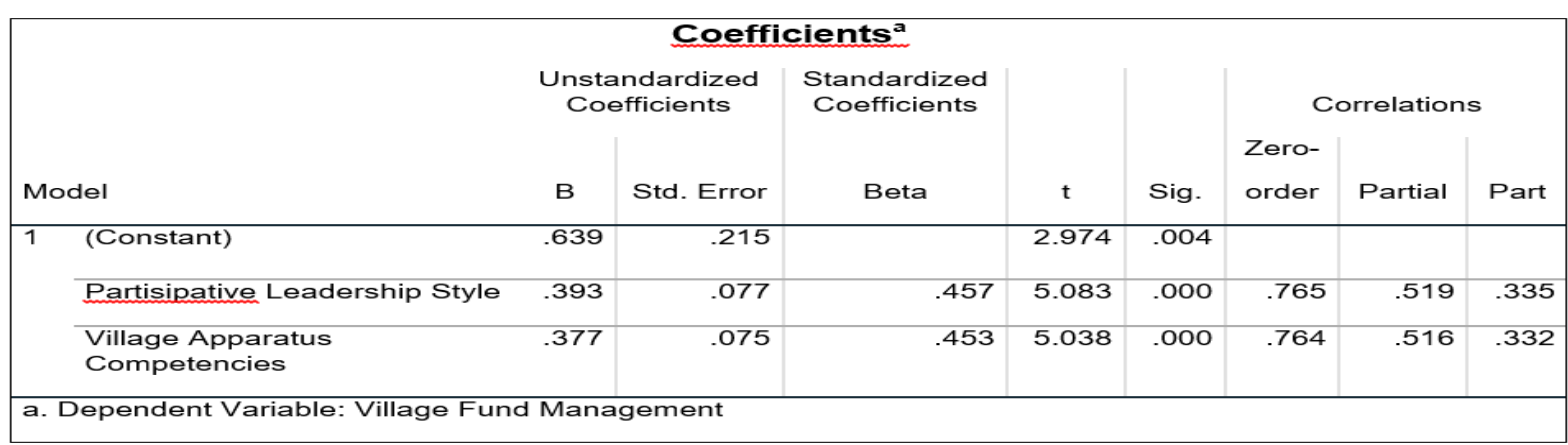

Based on information stated in Table 4, it indicates that the participative leadership style of village head and village apparatus competencies positively influences the performance of village fund management $(p<0,05)$. It means that the better leadership style of a leader will be able to influence many people to achieve the expected goals and the higher the competency of village apparatus, the higher the accountability of village fund 
management. The results are consistent with the previous researches that predict the leadership style of the village head and village apparatus competencies positively significantly influenced the performance of village fund management.

According to Sekaran (2013), the purpose of the partial test measures to what extent the influence of the independent variable on the dependent variable individually. Hypothesis testing was carried out using a significance level of 0.05 . The t-test in this study aims to determine the effect of independent variables consisting of the participative leadership style of the village head and village apparatus competencies on village fund management.

Based on information stated in Table 4, the results of the t-test statistic calculation for the participative leadership style of village head is 5,083 with a significance value of 0,000 and the $\mathrm{t}$-table is 1,667 . Because $\mathrm{t}$ table $<\mathrm{t}$ value, then the test result Ho was rejected. Therefore, the hypothesis that states the participative leadership style of the village head positively associated with the performance of village Fund management is supported.

Based on information stated in Table 4, the results of the t-test statistic calculation for competencies of village apparatus is 5.038 with a significance value of 0.000 , and the $t$ table is 1,667. Because of $t$ table $<\mathrm{t}$ value, then the test result Ho was rejected. Therefore, the hypothesis that state competency of village apparatus positively associated with the performance of village fund management is supported

\section{Discussion}

\section{Participative Leadership Style and performance of Village Funds Management}

According to Mulyadi and Rivai (2006), leadership style is behaviour and strategy that is liked and often applied by a leader in order to achieve organizational goals. Therefore, the leadership style of the village head should be associated to achieve the objectives of the village administration. A research conducted by Randhita (2009) shows that the leadership style that is mostly applied by successful headman is the participative leadership and consultative leadership style. The participative leadership style devotes all attention and gives opportunities to his subordinates to be able to participate through the contribution of ideas or suggestions in the process of management decision making. Finding in this research is in line with the similar previous research conducted by Made, et al (2014) and Suartana, et al. (2014) that participative leadership style has a positive influence on job satisfaction and financial performance. These results are supported by theory, according to Pors (2008) that leaders can act as agents of change.

\section{Competencies and Performance of Village Funds Management}

Finding in this study suggest that competence of village apparatus is positively associated with the performance of village funds management. The finding is supported by theory, according to Sutaryo (2011), employees with high human capital make it possible to provide consistent services and high competence. The previous research conducted with regard to the competence of village apparatus is the research of Mada et al. (2016) and Irma (2015) in which the results of his study mention that the competence of village apparatus has a positive and significant effect on the accountability of village fund management.

\section{Conclusion}

Based on the analysis and discussion in the previous section, the conclusions are as follows; 1) the participative leadership style of village head has a positive and significant impact on the performance of village fund management; 2) The village apparatus competencies has a positive and significant impact on the performance village fund management.

The limitation of this study is that the respondents involved in this research are the village head and village apparatus who are directly related to the variables of this research. Although the respondents assess their colleagues and themselves, the resulting answers can be biased so it needs to be considered for future researchers to replace the respondents if they use similar variables. 
In addition, suggestions for practitioners in the village government are as follows; 1) There is a need for particular training for village apparatus, such as training in the use of the village financial system (siskeudes) application computers because there are still village apparatus who have not been able to operate computers; 2) The village government needs to pay attention to updating information related to village activities and village finances on the website as a form of accountability for managing village finances to funders and the community.

Further suggestions for the future research are as follows: 1) Future researchers can broaden the scope of research by considering other factors that influence the management of village funds, such as the culture of village organizations, the village's internal control system, and other variables; 2) Future researchers must then consider respondents from third parties who will be taken in the research if they want to use variables that measure the performance of the village head or village apparatus such as the village community, Community Empowerment Institution (LPM), and others. It is in order to avoid respondents from evaluating themselves and answers that do not show the real condition.

\section{References}

Agung, Prasetyo Riky. (2018). The Influence of Village Government Competence, Control Systems Internal, and Financial Statement Accessibility to Management Accountability Village Fund (Case Study of Village Government in the City of Pariaman).

Atmadja, A T. (2018). Determinant Factors Influencing the Accountability of Village Financial Management. Academy of Strategic Management Journal. Ganesha Education University. Vol 17(1)

Aulia Yanuar, A. (2017). The Effect of Leadership Style, Competence and Compensation on Employee Performance at PT. Pertamina in Makassar. (Doctoral Dissertation), Universitas Hasanuddin.

Ekaningtyas, N. (2016). The Effect of Leadership Style on the Utilization of Village Budget (APBDes). Studi Pustaka, 3(1).
Fajri, Rahmi. (2015). Village Government Accountability in Village Fund Allocation Management (ADD) (Study at the Ketindan Village Office, Lawang District, Malang Regency). Public Administration Journal (JAP). Vol.3, No.7, Page 1099-1104.

Hersey, P., \& Blanchard, K. H. (1995). Management of Organizational Behavior. Jakarta: Erlangga.

Indah, P. A. (2019). The Influence of Spiritual Leadership Style and Competence of Village Officials on Accountability of Village Fund Management in Pasuruan Regency. Faculty of Economic-UM.

Indonesia, R. (2006). Regulation of The Minister of Home Affairs number 13 of 2006 concerning Regional Financial Management Guidelines. Jakarta.

(2013). Regulation of The National Civil Service Agency number 8 of 2013 concerning the Formulation of Technical Standards for Civil Servants. Jakarta. (2014). Law of The Republic of Indonesia number 6 of 2014. Jakarta. (2014). Regulation of The Minister of Home Affairs number 114 of 2014 concerning Village Development Guidelines. Jakarta. (2015). The Government Regulations Number 47 of 2015 concerning Regulation of Implementation of Law Number 6 of 2014 (Village Law). Jakarta . (2015). Regulation of The Minister of Home Affairs Number 84 of 2015 concerning the Composition of Village Government Work Arrangement Organizations. Jakarta (2018). Regulation of The Minister of Home Affairs Number 20 of 2018 concerning Village Financial Management. Jakarta.

Indrianasari, N. T. (2017). The Role of Village Officials in Village Financial Management Accountability. ASSETS: Journal of Accounting, Finance and Tax, $1(2), 29-46$.

Irma, Ade. (2015). Accountability Management of Village Fund Allocation (ADD) in Dolo sub-district, Sigi Regency. eJournal Katalogis. Vol.3, No.1, Page 121-137.

Kazimoto, P. (2013). Assessment of Villages Financial Management Challenges and Development Strategies in Tanzania, 
Arumeru District. International Journal of Research in Social Sciences, 3(2). ISSN 2307-227X.

Keating, C. J. (1986). Leadership: Theory and Development. Yogyakarta: Kanisius.

Kouzes, J. \& Posner, B. Z (2004). The Leadership Challenge. USA: John Willey and Sons, Inc.

Komisi XI. (2019, November 7). The Government are Investigate Fictitious Villages Receiving Village Funds. Available online at : http://www.dpr.go.id/berita/detail/id/263 73/

t/Pemerintah+Harus+Usut+Tuntas+Des a+Fiktif+Penerima+Dana+Desa

Kompas. (2019, November 9). The Fictitious Villages Recipient of Village Funds. Available online at : https://www.kompas.com/tren/read/201 9/11/09/0915002 65/mengenal-desadesa-fiktif-penerima-dana-desa?page $=$ all

Mada, S., Kalangi, L., \& Gamaliel, H. (2017). The Effect of Village Fund Management Officers Competencies, Village Government Organizational Commitment, And Community Participation in Village Fund Management Accountability in Gorontalo Regency. Journal of Accounting and Auditing "Goodwill", $8(2)$.

McCrimmon, M. (2007). Reframing Leadership for a Postmodern Age. Integral Leadership Review, 8(2), 2007 03 .

McPeak, D., Pincus, K. V., \& Sundem, G. L. (2012). The international accounting education standards board: influencing global accounting education. Issues in Accounting Education, 27(3), 743-750.

Majalah Media Akuntansi. (2014, October November). Beware of Village Funds Disbursement. [Online] Media Accounting Magazine, page. 28-31.

Makalalag, Astri Juainita. (2017). Accountability of Village Fund Management in Kotamobagu District. . Journal of Accounting and Auditing "Goodwill". Vol. 8, No. 1. Page 149158.

Mujahida, Sitti. (2018). Introduction to Management. Makassar: CV Sah Media 2018.
Mulia, R. A. (2019). Analysis of Factors Affecting the Quality of Regional Government Financial Statements (Study of the Government of West Pasaman Regency). EL-RIYASAH Journal, 9(1), 7-21.

Munti, F., \& Fahlevi, H. (2017). Determinants of Village Financial Management Performance: Study in Gandapura District, Bireuen District, Aceh. Journal of Accounting and Investment, 18(2), 172-182.

Nasrulloh, N. (2008). Group Dynamics and Leadership. Bandung: Widya Padjadjaran.

Needles Jr, B. E. (2005). Implementing International Education Standards: The Global Challenges. Accounting Education, 14(1), 123-129.

Nurhakim, I., \& Yudianto, I. (2018). Implementation of Village Fund Management. Journal of Accounting Auditing and Business, 1(2), 39-55.

Paripurna. (2019, July 16). The Problem of Village Fund Management. Available online at :

http://dpr.go.id/berita/detail/id/25283/t/P engelolaan+Dana+ Desa+

Masih+Bermasalah

Permana, R. (2016). The Role of Village Head Leadership in Long Beliu Village, Kelay Sub-District, Berau Regency. Ejournal Public Administration, 994-1006.

Randhita, R., \& Pengembangan, D. S. K. D. (2009). The Effect of Leadership Style on Employee Performance in Urban Government Organizations. Department of Communication Science and Community Development, Institut Pertanian Bogor.

Redaksi Desapedia. (2019, May 29). Village Fund Corruption. Available online at : https://www.desapedia.id/korupsi-danadesa-dari-mark-up-hingga-lpj-yangterlambat/

Risya, U., \& Nurodin, I. (2017). The Effect of Transparency and Accountability on Village Financial Management. Journal of Accounting, Tax \& Management, 6(11), 74-80.

Rivai, V. (2006). Leadership Tips in the 21st Century. Jakarta: Murai Kencana

(2006). Leadership and Organizational Behavior. Jakarta: Raja Grafindo Persada 
Robbins, S. P., \& Pujaatmaka, H. (2007). Organizational Behavior, Controversy Concepts, Applications. Jakarta: PT. Indeks. Gramedia.

Rosyidi. (2018). Internal Control of Village Funds (Case Study of All Village in Salo sub-district, Kampar Regency). Riau University, Pekanbaru, Indonesia 1(1): $1-14$.

Satyawati, N. M. R., \& Suartana, I. W. (2014). The Effect of Leadership Style and Organizational Culture on Job Satisfaction that Impacts Financial Performance. E-Journal of Accounting, 17-32.

Sedarmayanti, H. (2010). Human Resource Management; Bureaucratic Reform and Management of Civil Servants. Bandung: PT. Reflika Aditama.

Sekaran. (2013). Research Methods for Business (A Skill Building Approach) 5th Edition. New York: Wiley.

Setiawan, N. D., \& Yuliani, N. L. (2017). The Effect of Understanding and Role of Village Officials on Village Fund Management Accountability. University Research Colloquium, 205-210.

(Doctoral Dissertation), Universitas Diponegoro.

Sudriamunawar, H. (2006). Leadership, Participation and Productivity. Bandung: Mandar Maju.

Sunanto, E., \& Ismanudin. (2014). The Effect of Village Head Leadership on Government Administrative Services in the Field of Civil Services in Renjeng Village, Losarang Sub-District, Indramayu Regency. EJournal, Vol. 5, No.1, 1-24.

Syamsi, S. (2015). Community Participation in Controlling the Use of Village Fund Budgets. JISIP: Journal of Social and Political Sciences, Vol.3, No.1.

Wibowo, H. (2007). Method For Work Management, Jakarta: PT. Raja Grafindo Persada.
SHnet. (2018, Februari 8). Constraints on Siskeudes Implementation. Available online at http://sinarharapan.net/2018/02/inikendala-implementasi-siskeudes-versibpkp/

Siagian, S. P. (2003). Leadership as practice: Theory and application, Jakarta: PT. Rineke Cipta.

Simon, Y., Mas' ud, M., \& Su'un, M. (2016). The Role of Apparatus Competence, Internal Control System on Good Governance and The Quality of Financial Statement Information. Researchers World, 7(4), 123.

Suparman, E. (2014). Implementation of the Village Fund Allocation Program in the sub-district of Sukadana, North Kayong Regency. (Doctoral dissertation), Tanjungpura University.

Subroto, A. (2009). Village Fund Management Accountability (Case Study of Village Fund Allocation Management in Villages in the District of Tlogomulyo SubDistrict, Temanggung Regency in 2008).

Widyatama, A., Novita, L., \& Diarespati, D. (2017). The Effect of Competence and

Yukl, G.A. (1998). Leadership in Organizations. New Jersey: Prentice Hall

Yuliani. (2017). The Influence of Village Leadership Leaders to Financing The Development Program From Village Fund Allocations (Cibalung Village, Cijeruk Sub-District, Bogor Regency). Institut Pertanian Bogor

Yuliansyah, R. D. (2016). Village Accounting. Jakarta: Salemba Empat. 